\title{
Antimicrobial Activity of Intrinsic Antimicrobial Polymers Based on Poly((tert- butyl-amino)-methyl-styrene) Against Selected Pathogenic and Spoilage Microorganisms Relevant in Meat Processing Facilities
}

Carina Braun ${ }^{1 *}$, Sophia Dohlen ${ }^{1}$, Yvonne lg $^{2}$, Florian Brodkorb ${ }^{3}$, Björn Fischer ${ }^{3}$, Patrick Heindirk ${ }^{3}$, Katrin Kalbfleisch ${ }^{3}$, Thomas Richter ${ }^{3}$, Oliver Robers ${ }^{3}$, Martin Kreyenschmidt ${ }^{3}$, Reinhard Lorenz ${ }^{3}$ and Judith Kreyenschmidt ${ }^{3}$

${ }^{1}$ Institute of Nutritional and Food Sciences, Food Processing Engineering, University of Bonn, Katzenburgweg 7-9, Bonn, Germany

${ }^{2}$ Institute of Animal Science, Preventive Health Management Group, University of Bonn, Katzenburgweg 7-9, Bonn, Germany

${ }^{3}$ Department of Chemical Engineering, University of Applied Sciences Münster, Stegerwaldstraße 39, Steinfurt, Germany

*Corresponding author: Carina Braun, Institute of Nutritional and Food Sciences, Food Processing Engineering, University of Bonn, Katzenburgweg 7-9, Bonn, Germany, Tel: +49 22873 1941; Fax: +49 22873 6515; E-mail: cbraun@uni-bonn.de

Received date: January 23, 2017; Accepted date: February 27, 2017; Published date: March 6, 2017

Copyright: (c) 2017 Braun C, et al. This is an open-access article distributed under the terms of the Creative Commons Attribution License, which permits unrestricted use, distribution, and reproduction in any medium, provided the original author and source are credited.

\begin{abstract}
Objective: Antimicrobial materials are used as a possible approach to improve hygienic conditions in the food industry. The aim of this study was the investigation of the antimicrobial activity of the homopolymer of poly((tertbutyl-amino)-methyl-styrene) (poly(TBAMS)) and of the copolymer poly(TBAMS:acrylonitrile) [1:1] against microorganism present on meat processing equipment.
\end{abstract}

Method: Antimicrobial polymers were characterized by Fourier transform infrared spectroscopy and differential scanning calorimetry analysis. The antimicrobial activity against various pathogenic and spoilage bacteria ( $S$. aureus, E. coli, L. monocytogenes, Salmonella spp., Pseudomonas spp., B. thermosphacta) was determined using a modified test method based on the Japanese Industrial Standard JIS Z 2801: 2000. Furthermore, the influence of high initial bacterial counts (up to $8.9 \log _{10} \mathrm{cfu} / \mathrm{ml}$ ) as well as the exposure of bacteria in mixed cultures on the antimicrobial activity was evaluated.

Results: Spectroscopy identified the homopolymer poly(TBAMS) as well as a successful copolymerization with acrylonitrile. Results of antimicrobials tests showed significant reductions of bacterial counts on both polymers compared with the reference material of microorganisms in pure culture after 2 hour at $35^{\circ} \mathrm{C}$. L. monocytogenes, $E$. coli and $S$. aureus were reduced to the detection limit $\left(>4.2 \log _{10}\right.$-units). P. fluorescens was less sensitive to poly(TBAMS)-based films, especially to the copolymer. The homopolymer offers slightly higher activity than the copolymer, but glass transition temperature was lower. Tests with mixed cultures affirmed the dependency of activity on bacteria species. A tendency of higher antimicrobial activity against gram-positive was observed, if high initial counts were used; however, significant reduction of gram-negative were still determined.

Conclusion: Poly(TBAMS)-films show excellent antimicrobial properties against microorganisms relevant in meat processing facilities, and the implementation of those surfaces could contribute to improving the hygienic conditions during production and processing.

Keywords: SAM-Polymers`; Pathogens; Spoilage bacteria; Quality and safety of meat; Food contact surfaces; Antimicrobial surfaces; Contact active materials

\section{Introduction}

In the meat processing industry, a mixture of spoilage bacteria like Pseudomonas spp. or Brochothrix thermosphacta as well as pathogens like Staphylococcus aureus, Escherichia coli, Salmonella spp. and Listeria monocytogenes, is continuously prevalent [1-3]. The bacteria attach, grow and form multi-species biofilms on surfaces and consequently present a source of microbial contamination $[3,4]$. A crossover of bacteria from the contaminated food contact surfaces to meat could lead to deteriorative changes in the quality and safety of the products and to a decreased shelf life [2,5-9]. Therefore, the control and improvement of hygienic conditions during meat processing is of high importance. A promising procedure to improve the hygienic status of food contact surfaces is the application of antimicrobial materials in the food industry [10-13]. Due to the self-sterilizing effect of such surfaces, the bacterial contamination is reduced even between cleaning and disinfection steps and furthermore the treated surfaces are protected against biodegradation $[5,11,13,14]$.

In last decades, a wide spectrum of antimicrobial agents, ranging from plant extracts [15,16], enzymes [17], antimicrobial peptides [18] and metals [19-21] to bioactive polymers [22,23], were researched for the application in food contact materials $[12,24,25]$. Generally, the application can be conducted via integration of the agents in the material of food contact surfaces themselves or by coating existing surfaces.

Depending on the mode of biocidal action, the resulting surfaces are classified as biocide releasing or contact-active surfaces [26]. A new class of non-leaching, contact-active surfaces are SAM-Polymers ${ }^{\circledR}$ (sustainable active microbiocidal) [22]. Poly(tert-butyl-amino-ethyl)- 
Citation: Braun C, Dohlen S, llg Y, Brodkorb F, Fischer B, et al. (2017) Antimicrobial Activity of Intrinsic Antimicrobial Polymers Based on Poly((tert-butyl-amino)-methyl-styrene) Against Selected Pathogenic and Spoilage Microorganisms Relevant in Meat Processing Facilities. J Antimicrob Agents 3: 136. doi:10.4172/2472-1212.1000136

Page 2 of 9

methacrylate (poly(TBAEMA)) is the most comprehensively investigated agent in this polymer group. It has a good antimicrobial activity against a wide range of microorganisms, while exhibiting only a low toxicity in mammals [22]. It seems to be evident that the amino functionalized groups, located on the surface due to the threedimensional structure of the polymers, are responsible for the antimicrobial activity. Hewitt et al. [27] clarify that physical interactions, chemical reactions or a combination of both are required for the antimicrobial activity. The exposure of bacteria to the polymers initially leads to a depolarization of the cytoplasmic membrane resulting in permeability which initiates cell death through a release of fibrous and cellular material [27,28].

Lenoir et al. [28] assumed that the charged amino groups replace divalent cations of the outer membrane, which leads to membrane disorganization. A certain degree of protonation of the amino groups is necessary for the antimicrobial activity [29]. The resulting localized $\mathrm{pH}$-gradient and additional electrostatic interactions between the positively charged surface of the polymer and the negatively charged bacteria membrane are responsible for the antimicrobial activity.

In addition to the antimicrobial activity, the material properties are relevant for the implementation of antimicrobial surfaces in the food industry. According to Thölmann et al. [22], poly(TBAEMA) is insoluble in water, possesses a glass transition temperature $\mathrm{T}_{\mathrm{G}}$ of about $40^{\circ} \mathrm{C}$ and temperature stability up to $180^{\circ} \mathrm{C}$.

But this low $\mathrm{T}_{\mathrm{G}}$ is, next to its high water uptake, a weak point of poly(TBAEMA) [30], because it reduces the processability and usability of these polymers. Brodkorb et al. [30] developed and characterized a new monomer (tert-butyl-amino)-methyl-styrene (TBAMS). Poly(TBAMS), the corresponding intrinsic antimicrobial active polymer offers improved properties in comparison to poly(TBAEMA). Hence, poly(TBAMS) shows a $\mathrm{T}_{\mathrm{G}}$ of about $68^{\circ} \mathrm{C}$, which can be further increased by copolymerization [30]. In addition, the water uptake of poly(TBAMS) is low and the heat resistance is reasonable $[30,31]$.

Due to these material properties, polymer films based on TBAMS are potentially suited for the use as food contact material. Up to now, it is not clear if these polymers are active over the broad microbial spectrum which is typical in meat production and processing.

The aim of this study is the investigation of the antimicrobial activity of two films based on poly((tert-butyl-amino)-methyl-styrene) against various pathogenic and spoilage bacteria relevant in meat processing facilities. In the first step, therefore, two films with different poly(TBAMS)-concentrations were characterized via Fourier transform infrared (FTIR) spectroscopy, and differential scanning calorimetry (DSC) analyses were done to determine the $\mathrm{T}_{\mathrm{G}}$ as one important parameter for material usability as a food contact surface.

Subsequently, the antimicrobial activity of both films was screened against various pure bacteria cultures. In the next step, the effect of increased initial counts of bacteria on the antimicrobial activity of poly(TBAMS) films was tested.

In the third antimicrobial test series, mixed cultures containing Pseudomonas spp., a typical biofilm former, were used to simulate processing conditions and to investigate whether interactions between the bacteria species or different electrostatic interactions between bacterium and antimicrobial surfaces influence the antimicrobial activity against individual bacteria species.

\section{Materials and Methods}

\section{Antimicrobial test material}

Two polymer, the homopolymer poly(TBAMS) and the copolymer poly(TBAMS:acrylonitrile) [1:1], were investigated. Figure 1 shows the chemical structure of the polymers used. For each homopolymer sample, $125 \mathrm{mg}$ of purified polymer was dissolved in $3 \mathrm{ml}$ ethanol under stirring. The solution was then cast in a petri dish without vents (polystyrene, VWR, Germany) and dried in a vacuum drying cabinet at $70^{\circ} \mathrm{C}$ and $2 \mathrm{mbar}$ for 1 hour, resulting in colourless and transparent polymer films. For activity tests of the copolymer, a polyethylene film (40 $\mu \mathrm{m}$, corona pre-treated) was coated with a poly(TBAMS:acrylonitrile) [1:1] solution in ethylacetate, resulting in a $0.08 \mu \mathrm{m}$ thick layer of the copolymer, and trimmed into circular test pieces (94 $\mathrm{mm}$ in diameter). The reference material used depended on the sample material. Clear petri dishes of the same size (diameter: $94 \mathrm{~mm}$, without vents) and petri dishes with trimmed pieces of PE-film were used as references for the homopolymer and for the copolymer respectively.
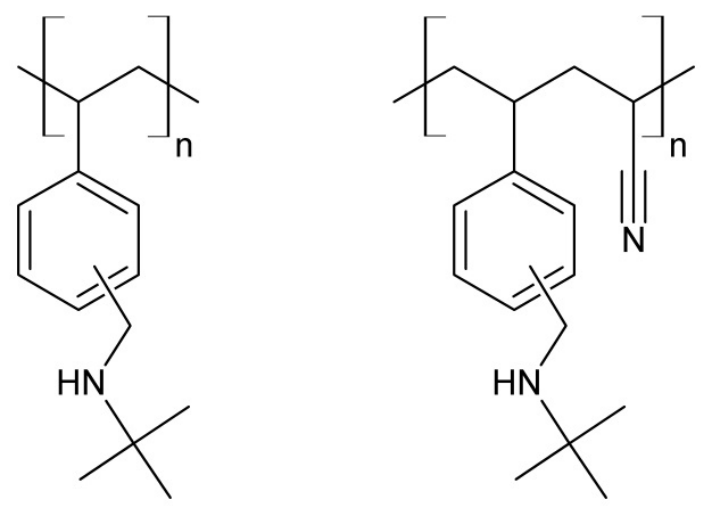

Figure 1: Chemical structure of poly(TBAMS) (left) and poly(TBAMS:acrylonitrile) (right) consisting of a mixture of metaand para-isomers.

\section{Characterization of polymers}

Infrared spectra were recorded via a Spectrum two FT-IR spectrometer (Perkin Elmer, Waltham, USA) with UATR two technique. The method was attenuated total reflection (ATR) in the range of $450 \mathrm{~cm}^{-1}$ to $4000 \mathrm{~cm}^{-1}$. Differential scanning calorimetry (DSC) analysis was carried out on a DSC 821e (Mettler Toledo, Greifensee, Swiss) system.

\section{Bacterial strains}

To test the antimicrobial activity nine typical pathogenic and spoilage microorganisms were chosen as test organisms (Table 1). For both categories, at least one gram-negative as well as one gram-positive representative bacterium was tested.

\section{Preparation of inoculum}

All bacteria strains were stored at $-18^{\circ} \mathrm{C}$ in a CRYOBANK ${ }^{\mathrm{TM}}$ system (Mast, Reinfeld, Germany). The inoculum was prepared by transferring a frozen culture to $10 \mathrm{ml}$ nutrient broth (Merck KGaA, 
Citation: Braun C, Dohlen S, llg Y, Brodkorb F, Fischer B, et al. (2017) Antimicrobial Activity of Intrinsic Antimicrobial Polymers Based on Poly((tert-butyl-amino)-methyl-styrene) Against Selected Pathogenic and Spoilage Microorganisms Relevant in Meat Processing Facilities. J Antimicrob Agents 3: 136. doi:10.4172/2472-1212.1000136

Page 3 of 9

Darmstadt, Germany). Afterwards the broth was incubated overnight at cultivating temperatures (Table 1). At the beginning of each trial, the overnight culture was diluted in physiological saline solution with tryptone (1 g/l) (Oxoid, Hampshire, United Kingdom) to a final concentration of $10^{5} \mathrm{cfu} / \mathrm{ml}$. In addition to the pure cultures, mixed cultures were used for the antimicrobial activity tests. In a first step the different gram-negative Pseudomonas spp. $(P$. aeruginosa, $P$. fluorescens, $P$. putida) were mixed with the gram-positive bacteria $B$. thermosphacta. In a second step, based on the results, $P$. fluorescens was mixed with the two pathogens $E$. coli or $L$. monocytogenes, which differ in gram reaction. For the mixed inocula, each culture was initially prepared and diluted separately, and the two different cultures were mixed in the final dilution step. For the tests with high initial concentrations (second experiment series) $0.1 \mathrm{ml}$ of the overnight cultures in nutrient broth were transferred in $10 \mathrm{ml}$ saline solution with tryptone and were incubated another night leading to concentrations of 6.6-8.9 $\log _{10} \mathrm{cfu} / \mathrm{ml}$. These solutions were used as inocula in the test trials.

\section{Test performance}

Tests were conducted on the basis of the Japanese Industrial Standard (JIS) Z 2801:2000, a quantitative method to investigate the antibacterial effectiveness of plastic surfaces treated with an antibacterial agent. The antibacterial effectiveness is determined by the value of antibacterial activity, which is defined as the difference of the logarithm ( $\log _{10}$-reduction) of the bacterial count on untreated materials (reference) and treated materials (sample) after inoculation with microorganisms and incubation under defined conditions.

Per test standard a minimum of three samples and six references were tested in every trial for each bacteria inocula in the experiment series. The total number of separate samples per bacteria strain varied between 3 and 33. Most separate samples were tested of the homopolymer against $S$. aureus to prove the reproducibility of the material's effect.

In all experimental series, the materials were inoculated with $0.4 \mathrm{ml}$ of bacteria solution. To prevent evaporation and to standardize the contact area, sterile PE films $\left(40 \times 40 \mathrm{~mm}^{2}\right)$ covered the inocula loosely. Three references were washed out immediately after inoculation ( $\mathrm{t}=0$ hour) by rinsing via pipette with $10 \mathrm{ml}$ soybeancasein digest broth with lecithin polysorbat (Roth, Karlsruhe, Germany) to determine the initial concentration.

Sample surfaces and remaining references were incubated at $35^{\circ} \mathrm{C}$ and high relative humidity (80-90\%) for 2 hour. Data loggers (Testo $174 \mathrm{H}$, Testo AG, Lenzkirchen, Germany) monitored the temperature and humidity in five-minute intervals. Afterwards ( $t=2$ hour), they were washed out in a similar manner. Viable counts of the pure culture tests of the first two test series were determined by counting the colonies on plate count agar (Roth, Karlsruhe, Germany) using the pour plate technique. Plates were incubated for 48 hour at the appropriate cultivating temperature of the bacteria (Table 1).

\begin{tabular}{|c|c|c|c|}
\hline Bacteria & Strain & $\begin{array}{l}\text { Cultivating } \\
\text { temperature }\end{array}$ & Selective medium \\
\hline Brochothrix thermosphacta & ATCC 20171 & $25^{\circ} \mathrm{C}$ & $\begin{array}{l}\text { Streptomycin inosit toluylene red agar (SIN agar) referring to } \\
\text { the method of Hechelmann [32] (Sheep Blood Agar Base, } \\
\text { Oxoid, Cambridge, UK) }\end{array}$ \\
\hline Listeria monocytogenes & ATCC 19111 & $37^{\circ} \mathrm{C}$ & $\begin{array}{l}\text { Listeria agar according to Ottaviani and Agosti (ALOA, Oxoid, } \\
\text { Cambridge, UK) }\end{array}$ \\
\hline Staphylococcus aureus & ATCC 6538 & $37^{\circ} \mathrm{C}$ & Baird Parker agar (Oxoid, Cambridge, United Kingdom) \\
\hline Escherichia coli & ATCC 8739 & $37^{\circ} \mathrm{C}$ & $\begin{array}{l}\text { Violet red bile dextrose agar (VRBD, Merck, Darmstadt, } \\
\text { Germany) }\end{array}$ \\
\hline Pseudomonas aeruginosa & ATCC 15442 & $30^{\circ} \mathrm{C}$ & $\begin{array}{l}\text { Pseudomonas agar with cetrimide sodium nalidixate (CN) } \\
\text { selective supplement }\end{array}$ \\
\hline Pseudomonas fluorescens & ATCC 13525 & $25^{\circ} \mathrm{C}$ & $\begin{array}{l}\text { Pseudomonas agar with cetrimide fucidin cephaloridine } \\
\text { (CFC) selective supplement (Oxoid, Cambridge, UK) }\end{array}$ \\
\hline Pseudomonas putida & ATCC 12633 & $25^{\circ} \mathrm{C}$ & $\begin{array}{l}\text { Pseudomonas agar with cetrimide sodium nalidixate (CN) } \\
\text { selective supplement }\end{array}$ \\
\hline $\begin{array}{l}\text { Salmonella enterica subsp. Enterica serovar Enteritidis } \\
\text { 9:g,m:- }\end{array}$ & DSM 14221 & $37^{\circ} \mathrm{C}$ & * \\
\hline $\begin{array}{l}\text { Salmonella enterica subsp. Enterica serovar } \\
\text { typhimurium }\end{array}$ & ATCC 14028 & $37^{\circ} \mathrm{C}$ & * \\
\hline
\end{tabular}

Table 1: Summary of tested bacteria, cultivating temperature, and used selective media in mixed cultures.

The tests of the first series were conducted with both types of films. For the experiments with high initial counts, the copolymer poly(TBAMS:acrylonitrile) [1:1] were used. In the third experimental series, the antimicrobial activity of the copolymer was tested against mixed cultures. The total viable counts (TVC) of the mixed culture were also enumerated on plate count agar (pour plate technique); to determine the individual bacterial counts, different selective media (drop plate technique), Table 1 , were used in addition to the plate count agar. Mentioned optimal cultivating temperatures were used for the selective media in the mixed culture test series, while the plate 
Citation: Braun C, Dohlen S, llg Y, Brodkorb F, Fischer B, et al. (2017) Antimicrobial Activity of Intrinsic Antimicrobial Polymers Based on Poly((tert-butyl-amino)-methyl-styrene) Against Selected Pathogenic and Spoilage Microorganisms Relevant in Meat Processing Facilities. J Antimicrob Agents 3: 136. doi:10.4172/2472-1212.1000136

Page 4 of 9

count agar plates were incubated at $30^{\circ} \mathrm{C}$ for the determination of total viable counts when the cultivating temperature of the two bacteria varied. Detection limits for all tests were determined to be $1.0 \log _{10}$ $\mathrm{cfu} / \mathrm{ml}$ for pour plate technique and $2.0 \log _{10} \mathrm{cfu} / \mathrm{ml}$ for drop plate technique.

\section{Analysis}

Reduction or growth on material after 2 hour incubation was calculated by subtracting the logarithmic average value of bacterial concentration on reference material immediately after inoculation $\left(\mathrm{N}_{\mathrm{t}=0}\right)$ from the average value of bacterial concentration on the reference (Ref) and sample (SAM) material after 2 hour incubation $\left(\mathrm{N}_{\mathrm{t}=2}\right)$ (Equation 1).

$$
f\left(N_{\text {Ref }, t=0}, N_{t=2}\right)=\log _{10}\left(N_{R e f, t=0}\right)-\log _{10}\left(N_{t=2}\right)
$$

Standard errors (df) were calculated following the Gaussian propagation of uncertainty (Equation 2).

$$
d f=\sqrt{\left(\frac{1}{N_{\text {Ref, } t=0} \times \ln 10} \times \mathrm{dN}_{\mathrm{t}}=0\right)^{2}+\left(\frac{-1}{\mathrm{~N}_{\mathrm{t}=2} \times \ln 10} \times \mathrm{dN}_{\mathrm{t}}=2\right)^{2}}
$$

where, $\mathrm{N}_{\text {Ref, } \mathrm{t}=0}=$ average bacterial concentration on the reference material immediately after inoculation; $\mathrm{d}=$ standard error, and $\mathrm{N}_{\mathrm{t}=2}=$ average bacterial concentration on the reference respectively sample material after 2 hour incubation, $\ln =$ natural logarithm base e.

The value of the antimicrobial activity was calculated by subtracting the logarithmic value of the viable counts on the sample material from the logarithmic value of the reference material after inoculation and incubation (Equation 3):

$$
\log _{10}-\text { reduction }=\log _{10}\left(\mathrm{~N}_{\text {Ref, } \mathrm{t}=2} / \mathrm{N}_{\mathrm{SAM}, \mathrm{t}=2}\right)
$$

where, $\mathrm{N}_{\text {Ref, } \mathrm{t}=2}=$ average of bacterial concentration on reference material, and $\mathrm{N}_{\mathrm{SAM}, \mathrm{t}=2}=$ average of bacterial concentration on sample material both after 2 hour incubation.

According to the JIS Z 2801:2000 a material can be characterized as antimicrobial if the calculated $\log _{10}$-reduction is $\geq 2.0$ after 24 hour at $35^{\circ} \mathrm{C}$. Statistical significance $(n>3)$ in reduction-levels was tested using the Mann-Whitney $\mathrm{U}$ test in SPSS 22 (IBM $^{\circledR}$ SPSS ${ }^{\circ}$ Statictics). Significance was defined as $\mathrm{p} \leq 0.05$. Figures of antimicrobial activity were generated with the statistical software program Origin $8.0 \mathrm{G}$ (OriginLab Corporation, Northampton, MA).

\section{Results and Discussion}

Both polymer films were characterized by FTIR and the spectra are depicted in Figure 2. For the homopolymer poly(TBAMS) the secondary amine (R-NH-R) is observed at $3310 \mathrm{~cm}^{-1}$. The aromatic hydrogen (Ar-H) is located at $3017 \mathrm{~cm}^{-1}$. The aromatic structure of poly(TBAMS) can be explained due to following bands: $1605 \mathrm{~cm}^{-1}$, $1510 \mathrm{~cm}^{-1}$ and $1443 \mathrm{~cm}^{-1}$. The aromatic system is meta $\left(704 \mathrm{~cm}^{-1}\right.$ and $\left.793 \mathrm{~cm}^{-1}\right)$ and para $\left(819 \mathrm{~cm}^{-1}\right)$ substituted. $2961 \mathrm{~cm}^{-1}, 2925 \mathrm{~cm}^{-1}$ and $2866 \mathrm{~cm}^{-1}$ indicate symmetric and asymmetrical stretching vibrations of $-\mathrm{CH}_{3}$ and $-\mathrm{CH}_{2}$ groups. The tertiary butyl group belongs to $1360 \mathrm{~cm}^{-1}$ and $1386 \mathrm{~cm}^{-1}$. Both wave numbers $1089 \mathrm{~cm}^{-1}$ as well as
$1019 \mathrm{~cm}^{-1}$ cannot be assigned to functional groups in poly(TBAMS) but they are characteristic. Results confirm with analyses of Brodkorb et al. [30] and identified the used material as the newly described SAM-Polymer ${ }^{\oplus}$.

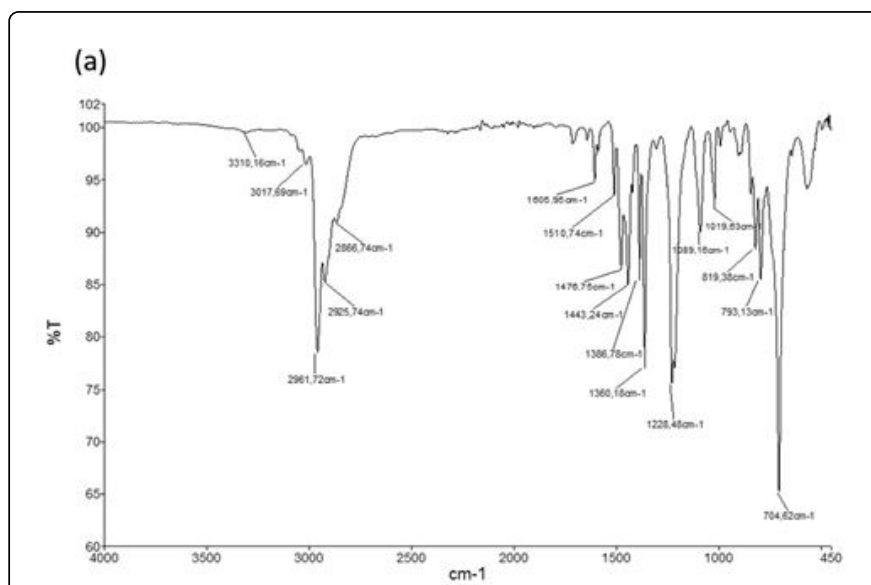

(b)

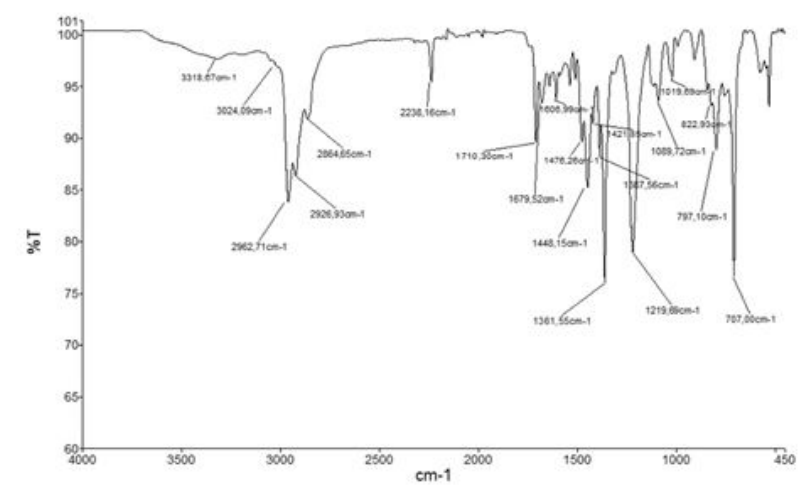

Figure 2: FTIR-ATR spectrum of the homopolymer poly(TBAMS) (a) and of the copolymer poly(TBAMS:acrylonitrile) (b).

For the copolymer used, the nitrile group (R-CN) is observed at $2238 \mathrm{~cm}^{-1}$, whereas the other bands show almost the same wave numbers and characteristics compared with poly(TBAMS), proving a successful copolymerization. The copolymerization increased the $\mathrm{T}_{\mathrm{G}}$ from $68^{\circ} \mathrm{C}$ for the homopolymer, to $103^{\circ} \mathrm{C}$ for the copolymer (Figure 3). The $T_{G}$ is one important parameter for the processability and usability of the polymers as a food contact material. Thus, the copolymer offers better material properties (higher $\mathrm{T}_{\mathrm{G}}$ and lower water uptake) than the homopolymer, but copolymerization can possibly influence the antimicrobial activity. Thus, both materials were screened for antimicrobial activity. The antimicrobial tests revealed good antimicrobial properties against various bacteria relevant in meat processing facilities for both tested intrinsic antimicrobial polymers based on poly((tert-butyl-amino)-methyl-styrene). Figure 4a shows the reduction of bacterial count observed on the reference material and the homopolymer poly(TBAMS) after 2 hour contact at $35^{\circ} \mathrm{C}$. Comparing the reductions of all bacteria, significantly more bacteria were reduced on poly(TBAMS) then on the reference material $(\mathrm{p}<0.001)$. The highest reduction was determined for $E$. coli, which was decreased from an initial average concentration of $5.73 \pm 0.01 \log _{10} \mathrm{cfu} / \mathrm{ml}$ down to the detection limit $\left(1.0 \log _{10} \mathrm{cfu} / \mathrm{ml}\right)$ on all samples $(\mathrm{n}=12)$. 
Citation: Braun C, Dohlen S, llg Y, Brodkorb F, Fischer B, et al. (2017) Antimicrobial Activity of Intrinsic Antimicrobial Polymers Based on Poly((tert-butyl-amino)-methyl-styrene) Against Selected Pathogenic and Spoilage Microorganisms Relevant in Meat Processing Facilities. J Antimicrob Agents 3: 136. doi:10.4172/2472-1212.1000136

Page 5 of 9
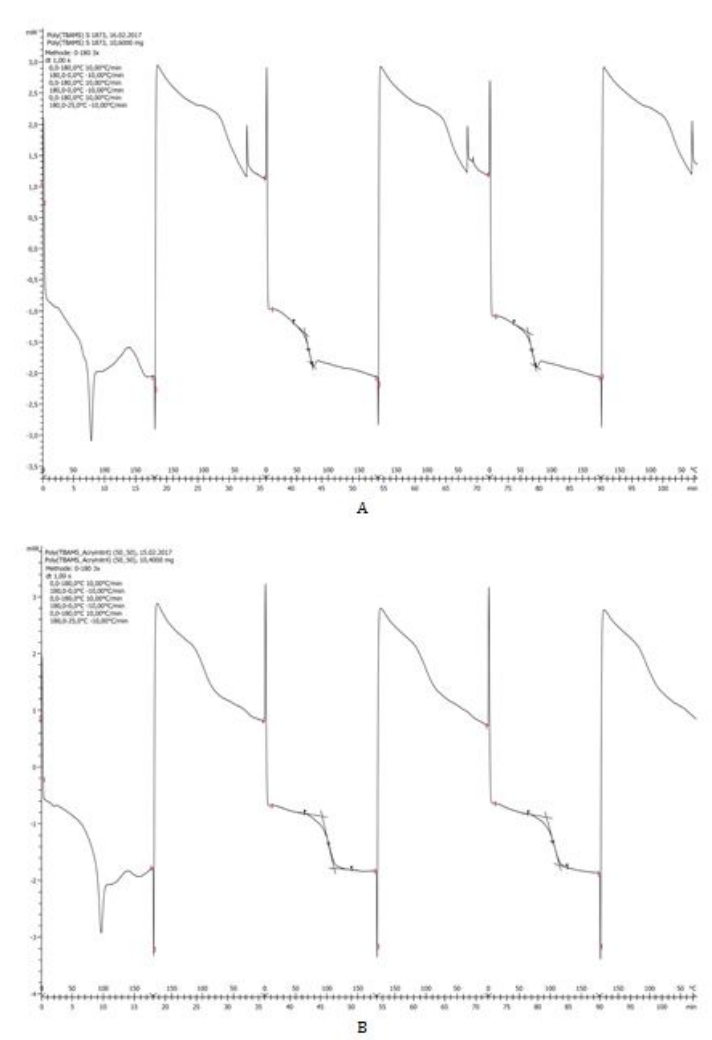

Figure 3: DSC analysis of poly(TBAMS) (A) and poly(TBAMS:acrylonitrile) (B).

At the same time, E. coli showed the second highest growth on the reference material during two hours; the high increase of bacterial count on the reference material, in conjunction with the high initial count, results in the observation of the highest $\log _{10}$-reduction of $5.6 \log _{10}$-steps. The bacterial counts of gram-positive $L$. monocytogenes, $S$. aureus and gram-negative $P$. aeruginosa were reduced to detection limit.

The $\log _{10}$-reductions of the tested bacteria vary among 2.4 and 5.6 $\log _{10}$-steps, which classify the material as antimicrobial according to the JIS already after 2 hour at $35^{\circ} \mathrm{C}$. The gram-negative bacteria $S$. enterica (Serovar enteritidis) was the less sensitive bacteria, however, the bacterial count on poly(TBAMS) was reduced $2.4 \log _{10}$-steps in comparison to reference material.

A total of 33 samples of the homopolymer poly(TBAMS) were tested with $S$. aureus to investigate the reproducibility of the material. The low standard error $\left(4.5 \pm 0.03 \log _{10} \mathrm{cfu} / \mathrm{ml}\right)$ of the bacterial reduction of the sample material shows the high reproducibility of the antimicrobial activity of the poly(TBAMS).

To test if copolymerization influences the antimicrobial activity of poly(TBAMS), the copolymer with acrylonitrile [1:1] applied as a coating was also tested against the mentioned bacteria. Thin coatings are the most common concept to add antimicrobials on the outside of materials, because this form enables the subsequent equipment of established food contact surfaces with antimicrobial properties [13], while the good properties of the used materials are not affected by integration of antimicrobial agents in the materials themselves [33].
Results of the copolymer poly(TBAMS:acrylonitrile) are comparable to those of the homopolymer. Also, a significant difference $(\mathrm{p}<0.001)$ between the reference and the sample material could be observed (Figure $4 \mathrm{~b}$ ), but the comparison of the reductions of all bacteria together shows a trend of a better activity of the homopolymer. A reduced activity against $P$. fluorescens is mainly responsible for this trend $\left(\log _{10}\right.$-reduction: 1.2$)$. For remaining bacteria, high $\log _{10^{-}}$ reductions (3.4-5.7), which characterize the material as antimicrobial active according to JIS Z 2801, could be detected.

For the pathogenic bacteria E. coli, L. monocytogenes and S. aureus, as well as for spoilage bacteria $B$. thermosphacta, $P$. aeruginosa and $P$. putida a reduction down or close to detection limit were proven. General, the charge of the antimicrobial surface plays an important role in electrostatic interactions between polymer surface and bacteria, and so for the antimicrobial activity.

The more active groups are present on the surface, the higher the antimicrobial activity is expected to be [34], because the number and availability of active groups determines the charge of the polymer. Thus, the homopolymer poly(TBAMS) shows a higher reduction $(p=0.001)$ when comparing counts of all tested bacteria together then the copolymer, which features less positive surface charge. Also, Potter et al. [35] detected decreased antimicrobial activity for modified cationic antimicrobial peptides with decreased electrophoretic mobility.

The dose-dependent activity of poly(TBAMS) conforms to the investigations on poly(TBAEMA) [28,34,36,37]. Zuo et al. [37] determined a correlation between the dosage of poly(TBAEMA) and the molecular weight of the macromolecules to the antimicrobial activity. The authors explain that a higher molecular weight results in a higher local congregation of active groups with a resulting increase in charge density and electrostatic attraction. Seyfriedsberger et al. [34] proved a correlation between the physio-chemical surface properties and the relative amount of poly(TBAEMA) in a compound with LDPE.

In the study, the antimicrobial activity against $E$. coli increased with an increasing relative amount of poly(TBAEMA). Interestingly, for $S$. aureus there was no difference in activity between the concentrations; $S$. aureus was reduced to zero independently of the poly(TBAEMA)concentration [34]. Furthermore, Zuo et al. [37] showed that, in general, $S$. aureus is more susceptive to poly(TBAEMA) then E. coli, but, particularly at lower local concentrations of active groups, the effect of molecular weight is different between $E$. coli and $S$. aureus.

A relationship between dose-dependence and bacteria species is in accordance with the present study. Particularly the antimicrobial effect on the gram-negative $P$. fluorescens is notably lower using the copolymer with only $50 \%$ poly(TBAMS) in comparison to the homopolymer. Otherwise, the antimicrobial activity against $S$. aureus was not affected by reducing the percentage of poly(TBAMS) in a poly(TBAMS:acrylonitrile) copolymer down to $20 \%$ (data not shown).

Other authors also proved good antimicrobial properties of SAMPolymers ${ }^{\otimes}$ against gram-positive $(S$. aureus, $L$. innocua, $L$. monocytogens, Lactobacillus spp., S. mutans, $S$. epidermidis, $B$. thermosphacta) and gram-negative $(E$. coli, $P$ aeruginosa, $P$. fluorescens) bacteria [22,28,29,36-39]. 
Citation: Braun C, Dohlen S, llg Y, Brodkorb F, Fischer B, et al. (2017) Antimicrobial Activity of Intrinsic Antimicrobial Polymers Based on Poly((tert-butyl-amino)-methyl-styrene) Against Selected Pathogenic and Spoilage Microorganisms Relevant in Meat Processing Facilities. J Antimicrob Agents 3: 136. doi:10.4172/2472-1212.1000136

Page 6 of 9

a
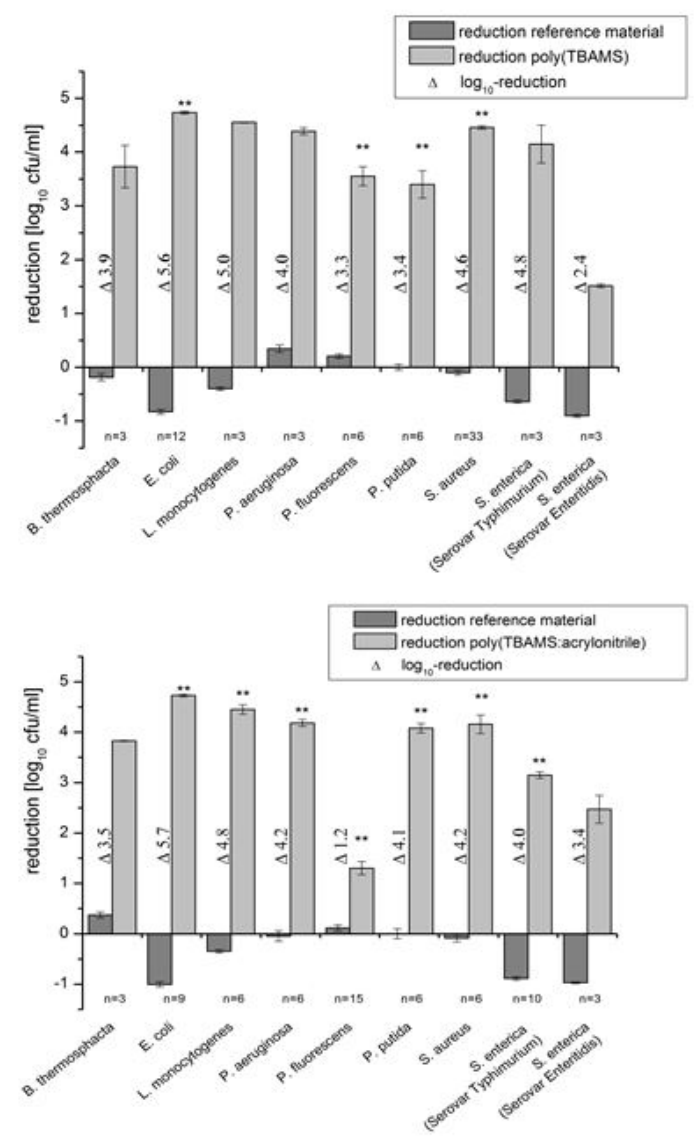

Figure 4: Reduction $\left[\log _{10} \mathrm{cfu} / \mathrm{ml}\right]$ of bacteria after 2 hour incubation at $35^{\circ} \mathrm{C}$ applied on reference material (dark grey bars) or sample material (light grey bars): (a) homopolymer poly(TBAMS) or (b) copolymer poly(TBAMS:acrylonitrile). The values are changes from initial concentration (a: 4.9- $5.9 \log _{10} \mathrm{cfu} / \mathrm{ml}, \mathrm{b}: 4.8-$ $\left.5.7 \log _{10} \mathrm{cfu} / \mathrm{ml}\right)$. The delta values are the differences between the surface counts on reference material and on sample material after incubation ( $\log _{10}$-reduction). Asterisks indicate significant differences $\left({ }^{* *} \mathrm{p} \leq 0.005,{ }^{*} \mathrm{p} \leq 0.05\right)$ between sample and reference material $(\mathrm{n}>3)$.

Nevertheless, some studies observed that gram-positive species are more sensitive than gram-negative bacteria [27,34,39]. In the study of Hewitt et al. [27], almost all cells of $S$. epidermidis exhibit depolarized, permeablised, cytoplasmic membrane potential after $30 \mathrm{~min}$ exposure to $0.1 \%$ poly(TBAEMA) suspension; whereas after 5.5 hour, only $59 \%$ of $P$. fluorescens cells showed the same status. In contrast, Buranasompob [29] detected a higher reduction of the gram-negative $P$. aeruginosa in comparison to $L$. innocua. In the present study for the biofilm former $P$. aeruginosa, high antimicrobial activity of both tested materials made from TBAMS was also detected. A general trend of a dependence of antimicrobial activity on gram reactivity was not observed at initial counts around $10^{5} \mathrm{cfu} / \mathrm{ml}$. At higher initial counts (6.6-8.9 $\log _{10} \mathrm{cfu} / \mathrm{ml}$ ) however, a trend of higher reduction of grampositive bacteria than gram-negative bacteria became visible.

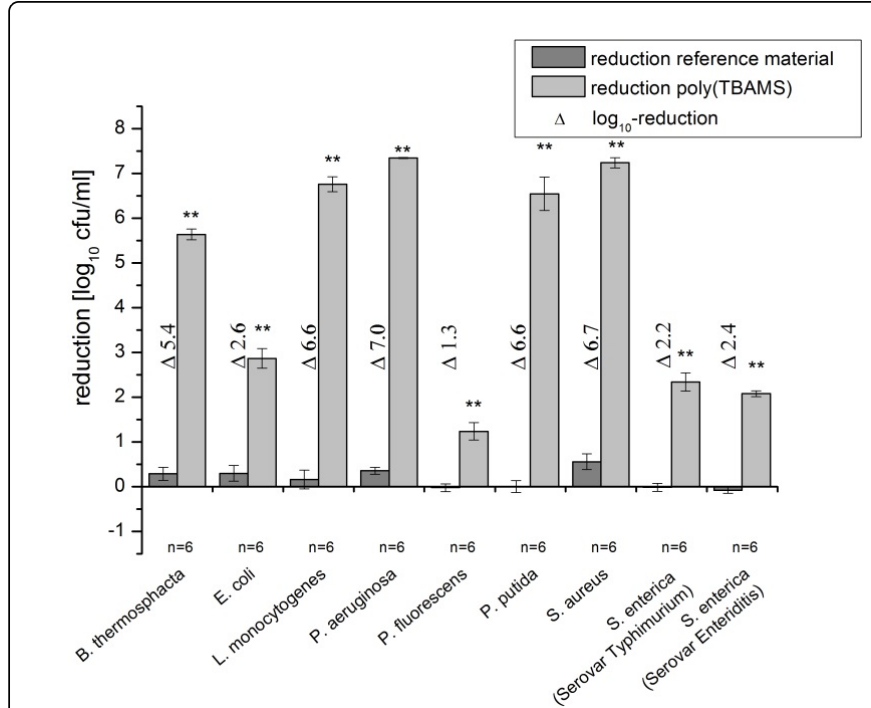

Figure 5: Reduction $\left[\log _{10} \mathrm{cfu} / \mathrm{ml}\right]$ of overnight cultures of bacteria in saline solution with tryptone applied on reference material (dark grey bars) or poly(TBAMS) (light grey bars) incubated at $35^{\circ} \mathrm{C}$ for 2 hour. The values are changes from initial concentration (6.6-8.9 $\left.\log _{10} \mathrm{cfu} / \mathrm{ml}\right)$. The delta values are the differences between the surface counts on reference material and on poly(TBAMS) after incubation ( $\log _{10}$-reduction). Asterisks indicate significant differences $\left({ }^{* *} \mathrm{p} \leq 0.005\right)$ between poly(TBAMS) and reference material.

Figure 5 shows the reduction values of the high initial bacterial counts, which are typical during industrial processing. Analysing the reduction of all bacteria together, the reduction on the sample material is significantly higher than on the reference material $(p<0.001)$. For the homopolymer film, the decrease of the initial bacterial count is highly significant for all bacteria $(\mathrm{p} \leq 0.001)$ with reductions between 1.2 and $7.3 \log _{10} \mathrm{cfu} / \mathrm{ml}$. The three tested gram-positive bacteria were reduced down to the detection limit. Very high $\log _{10}$-reductions (7.0 and 6.7 $\log _{10} \mathrm{cfu} / \mathrm{ml}$ ) were identified for the gram-negative bacteria $P$. aeruginosa and $P$. putida also.

These results are comparable with the results of moderate initial counts, but, for the remaining tested gram-negative bacteria, the antimicrobial activity was decreased. Particularly noticeable is the low reduction of $E$. coli $\left(2.6 \log _{10} \mathrm{cfu} / \mathrm{ml}\right)$, which was reduced in higher values during 2 hour if it was exposed in moderate initial concentration. Also, Zuo et al. [37] showed a higher antimicrobial activity of poly(TBAEMA) film for gram-positive $S$. aureus than for gram-negative $E$. coli at high initial bacterial load. The higher resistance of selected gram-negative bacteria, which became visible at high initial counts, can be charge of the outer membrane. Hewitt et al. [27] showed that the $P$. fluorescens cells become more sensitive to the poly(TBAEMA) suspension if the outer membrane of is permeabilised with EDTA.

The surface charge of bacteria itself plays, next to the charge of the polymeric surface, an important role for antimicrobial activity. In general, most bacteria carry a net negative surface charge under most physiological conditions [40]. According to Potter et al. [35], the electrophoretic mobility of the, for the present study, relevant grampositive bacteria (B. thermosphacta, $S$. aureus, $L$. monocytogenes) was 
Citation: Braun C, Dohlen S, Ilg Y, Brodkorb F, Fischer B, et al. (2017) Antimicrobial Activity of Intrinsic Antimicrobial Polymers Based on Poly((tert-butyl-amino)-methyl-styrene) Against Selected Pathogenic and Spoilage Microorganisms Relevant in Meat Processing Facilities. J Antimicrob Agents 3: 136. doi:10.4172/2472-1212.1000136

Page 7 of 9

more negative than for tested gram-negative bacteria (P. fluorescens, $S$. enterica, E. coli $)$. The authors proved a correlation between the electrophoretic mobility and the antimicrobial efficiency of a cationic antimicrobial peptide. Thus, the nearly neutral charge of $P$. fluorescens could cause the decreased activity of TBAMS-based films compared to the more negative charged bacteria. Furthermore, Kurinčič et al. [41] showed high electrophoretic mobility comparability between the $P$. aeruginosa strain used in this study and Listeria spp., which could explain the differences in activity against the three Pseudomonas spp. used. The effect of the electrophoretic mobilities of the bacteria is more distinctive at high than at moderate initial concentration. Next to the electrostatic interactions, the availability of active groups is also proportional to the number of bacterial count. Lenoir et al. [28] revealed that killed cells do not remain on the surface, potentially allowing an extension of contact time to achieve successive killing of bacteria, leading to comparable results in moderate initial concentrations. Likewise, longer contact could compensate the lower number of active groups in the copolymer and lead to comparable results as detected for the homopolymer.

Under practical conditions, bacteria colonize surfaces not as pure cultures, but rather as mixed bacteria populations and mostly in the form of biofilms. Pseudomonas spp., as ubiquitous spoilage organisms and great biofilm formers [42] were used in all cultures of the last experiments, because it is known, that their presence promotes the attachment and survival of pathogens, like L. monocytogenes, on surfaces $[43,44]$. When Pseudomonas spp. and B. thermosphacta, another dominant spoilage bacteria of fresh meat [45], were inoculated together, it became evident that the antimicrobial activity of poly(TBAMS:acrylonitrile) against the individual bacteria in the mixed culture is comparable to the results of the pure culture test series (Figure 6a).

The copolymer showed maximum reduction to the detection limit for $B$. thermosphacta as well as against $P$. putida and $P$. aeruginosa, and decreased activity against $P$. fluorescens. The TVC of the mixed culture of $B$. thermosphacta and $P$. fluorescens were reduced $2.4 \log _{10}$-steps, while the results on selective media show obviously, that only $P$. fluorescens survived on poly(TBAMS:acrylonitrile). Furthermore, it was investigated if this resilience of $P$. fluorescens protects cohabitating pathogens against the antimicrobial action of poly(TBAMS)containing films.

Analogous to pure cultures tests and to mixed tests with the spoilage bacteria $B$. thermosphacta, the counts of the pathogens were reduced down to the detection limit within 2 hour at $35^{\circ} \mathrm{C}$ and P. fluorescens represents the remaining TVC (Figure $6 \mathrm{~b}$ ). Investigations with the homopolymer indicate that the presence of $P$. fluorescens do not have an impact on the activity against the pathogens $S$. aureus and $S$. enterica, too (data not shown).

Thus, the less sensitivity of $P$. fluorescens does not affect the good antimicrobial activity of poly(TBAMS)-based films against the different microorganisms. The electrostatic interactions between the bacteria and the polymer surface seem to differ between the individual bacteria species, but have no effect on the individual antimicrobial activities in mixed bacteria cultures.

The reduction of Pseudomonas spp., which are known members of biofilms in the food industry, promises a potential reduction of biofilm formation and should be investigated further. Especially the fact that main pathogens associated with meat are significantly reduced on
poly(TBAMS)-containing films has a considerable impact for enhanced food security.

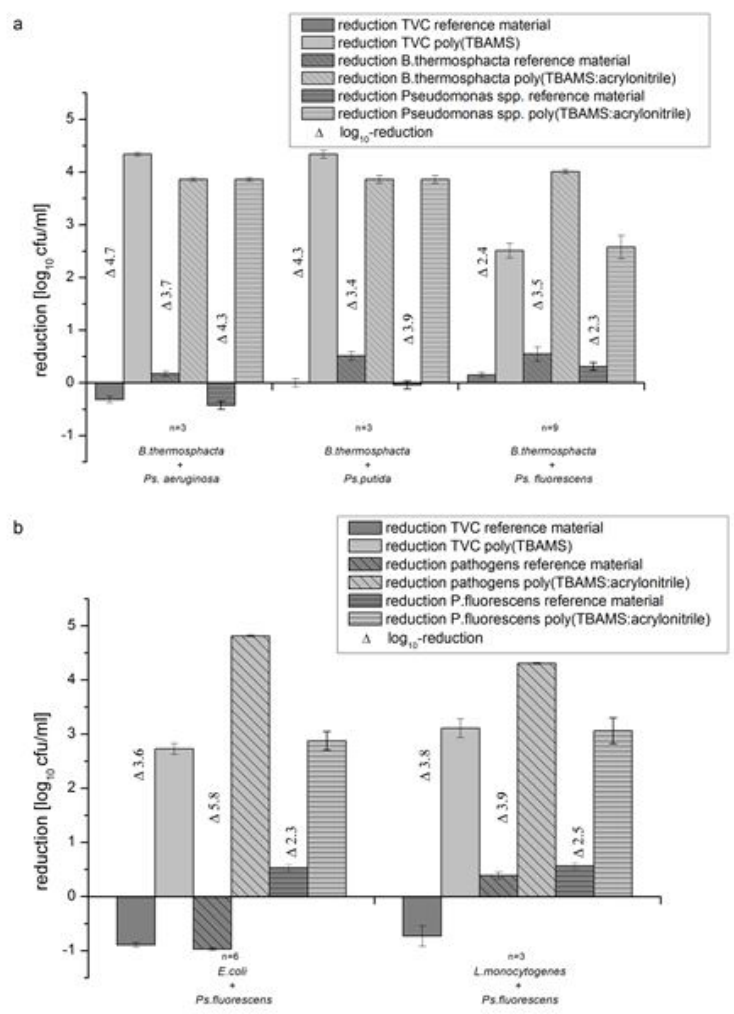

Figure 6: Reduction $\left[\log _{10} \mathrm{cfu} / \mathrm{ml}\right]$ of mixed cultured bacteria: (a) $B$. thermosphacta with Pseudomonas spp., (b) P. fluorescens with E. coli or L. monocytogenes applied on reference material (dark grey bars) on reference material or poly(TBAMS:acrylonitrile) (light grey bars) incubated at $35^{\circ} \mathrm{C}$ for 2 hour. The values of the plain bars are the changes from initial concentration of the total viable count (TVC); the patterned bars are the changes of the individual bacteria counts. The delta values are the differences between the surface counts on reference material and on poly(TBAMS:acrylonitrile) after incubation ( $\log _{10}$-reduction).

\section{Conclusion}

Regarding the two poly(TBAMS)-containing films tested, it can be summarized that a good antimicrobial activity exists against a wide range of pathogenic and spoilage bacteria relevant in meat processing facilities, both in pure or in mixed bacteria cultures. Effects on antimicrobial activity due to copolymerization, with the resulting concentration reduction of poly(TBAMS), or higher initial bacterial counts were mainly dependent on the sensitivity of the bacteria itself. The surface counts of pathogenic bacteria with high relevance in foodassociated diseases were reduced in comparison to the reference material, whereas the spoilage bacterium $P$. fluorescens was not that susceptible.

Due to these results and the improved material properties, the application of SAM-Polymer ${ }^{\oplus}$-surfaces based on poly((tert-butyl- 
Citation: Braun C, Dohlen S, llg Y, Brodkorb F, Fischer B, et al. (2017) Antimicrobial Activity of Intrinsic Antimicrobial Polymers Based on Poly((tert-butyl-amino)-methyl-styrene) Against Selected Pathogenic and Spoilage Microorganisms Relevant in Meat Processing Facilities. J Antimicrob Agents 3: 136. doi:10.4172/2472-1212.1000136

Page 8 of 9

amino)-methyl-styrene) could be an additional hurdle for bacterial growth on food contact surfaces such as cutting boards or conveyer belts and thus could counteract cross-contamination. Further development and characterisation of the material is required before application.

In future, the antimicrobial activity of the material, with due consideration of environmental factors existing in the food industry, should be investigated to check the efficiency of poly(TBAMS) films under real conditions. Furthermore, the effect of poly(TBAMS) films on biofilm formation should be studied.

\section{Acknowledgements}

The project was partly financed by a phd scholarship of the Heinrich Stockmeyer Foundation and was supported by funds of the Federal Ministry of Economics and Technology within the framework InnoNet (contract number 16INO640; Verbund-Nr. 01063175) and the Federal Ministry of Food and Agriculture (BMEL) based on a decision of the Parliament of the Federal Republic of Germany via the Federal Office for Agriculture and Food (BLE) under the innovation support programme (contract number 313-06.01-28-1-68.034-10) (Safe Pack).

\section{Conflict of interest}

No conflict of interest declared.

\section{References}

1. Bagge-Ravn D, Ng Y, Hjelm M, Christiansen JN, Johansen C, et al. (2003) The microbial ecology of processing equipment in different fish industries- analysis of the microflora during processing and following cleaning and disinfection. Int J Food Microbiol 87: 239-250.

2. Gounadaki AS, Skandamis PN, Drosinos EH, Nychas GJE (2008) Microbial ecology of food contact surfaces and products of small-scale facilities producing traditional sausages. Food Microbiol 25: 313-323.

3. Giaouris E, Heir E, Desvaux M, Hébraud M, Møretrø T, et al. (2015) Intra- and inter-species interactions within biofilms of important foodborne bacterial pathogens. Front Microbiol 6: 841.

4. Carrasco E, Morales-Rueda A, García-Gimeno RM (2012) Crosscontamination and recontamination by Salmonella in foods: A review. Food Res Int 45: 545-556.

5. Bower CK, McGuire J, Daeschel MA (1996) The adhesion and detachment of bacteria and spores on food-contact surfaces. Trends Food Sci Technol 7: 152-157.

6. Brooks JD, Flint SH (2008) Biofilms in the food industry: problems and potential solutions. Int J Food Sci Technol 43: 2163-2176.

7. Giaouris E, Chorianopoulos N, Skandamis P, Nychas G-J (2012) Attachment and biofilm formation by Salmonella in food processing environments. InTech pp: 157-180.

8. Møretrø T, Langsrud S, Heir E (2013) Bacteria on meat abattoir process surfaces after sanitation: characterisation of survival properties of listeria monocytogenes and the commensal bacterial flora. AiM 03: 255-264.

9. Giaouris E, Heir E, Hébraud M, Chorianopoulos N, Langsrud S, et al. (2014) Attachment and biofilm formation by foodborne bacteria in meat processing environments: Causes, implications, role of bacterial interactions and control by alternative novel methods. Meat Sci 97: 298-309.

10. Gundelley R, Youm GW, Kwon YM (2007) Survival of bacterial pathogens on antimicrobial conveyer belts. J Rapid Meth Aut Mic 15: 259-266.

11. Møretrø T, Langsrud S (2011) Effects of materials containing antimicrobial compounds on food hygiene. J Food Prot 74(7): 1200-1211.
12. Ilg Y, Kreyenschmidt J (2012) Review: Benefits and risks of the use of antimicrobial components in the food chain. J Food Saf Food Qual 63: 28-34.

13. Moerman F (2014) Antimicrobial materials, coatings and biomimetic surfaces with modified microtography to control microbial fouling of product contact surfaces within food processing equipment: Legislation, requirements, effectiveness and challenges. JHED 7: 8-29.

14. Appendini P, Hotchkiss JH (2002) Review of antimicrobial food packaging. Innovative Food Sci Emerging Technol 3: 113-126.

15. Gutierrez J, Barry-Ryan C, Bourke P (2008) The antimicrobial efficacy of plant essential oil combinations and interactions with food ingredients. Int J Food Microbiol 124: 91-97.

16. Ramos M, Jiménez A, Peltzer M, Garrigós MC (2012) Characterization and antimicrobial activity studies of polypropylene films with carvacrol and thymol for active packaging. J Food Eng 109: 513-519.

17. Barbiroli A, Bonomi F, Capretti G, Iametti S, Manzoni M, et al. (2012) Antimicrobial activity of lysozyme and lactoferrin incorporated in cellulose-based food packaging. Food control 26: 387-392.

18. Héquet A, Humblot V, Berjeaud JM, Pradier CM (2011) Optimized grafting of antimicrobial peptides on stainless steel surface and biofilm resistance tests. Colloids and Surfaces B: Biointerfaces 84: 301-309.

19. Noyce JO, Michels H, Keevil CW (2006) Use of copper cast alloys to control Escherichia coli O157 cross-contamination during food processing. Appl Environ Microbiol 72: 4239-4244.

20. Ilg Y, Kreyenschmidt J (2011) Effects of food components on the antimicrobial activity of polypropylene surfaces containing silver ions (Ag +). Int J Food Sci Technol 46: 1469-1476.

21. Kursunlu AN, Guler E, Sevgi F, Ozkalp B (2013) Synthesis, spectroscopic characterization and antimicrobial studies of $\mathrm{Co}(\mathrm{II}), \mathrm{Ni}(\mathrm{II}), \mathrm{Cu}(\mathrm{II})$ and $\mathrm{Zn}$ (II) complexes with Schiff bases derived from 5-bromosalicylaldehyde. J Mol Struct 1048: 476-481.

22. Thölmann D, Kossmann B, Sosna F (2003) Polymers with antimicrobial properties. EC Journal: 16-33.

23. Dutta PK, Tripathi S, Mehrotra GK, Dutta J (2009) Perspectives for chitosan based antimicrobial films in food applications. Food Chem 114: 1173-1182.

24. Bastarrachea LJ, Denis-Rohr A, Goddard JM (2015) Antimicrobial food equipment coatings: Applications and challenges. Annu Rev Food Sci Technol 6: 97-118.

25. Mauriello G (2016) Control of microbial activity using antimicrobial packaging. Jorge Antimicrobial Food Packaging. Elsevier pp: 141-152.

26. Tiller JC (2011) Antimicrobial Surfaces. Springer Berlin Heidelberg pp: 193-217.

27. Hewitt CJ, Franke R, Marx A, Kossmann B, Ottersbach P (2004) A study into the anti-microbial properties of an amino functionalised polymer using multi-parameter flow cytometry. Biotechnol Lett 26: 549-557.

28. Lenoir S, Pagnoulle C, Galleni M, Compère P, Jérôme R, et al. (2006) Polyolefin matrixes with permanent antibacterial activity: Preparation, antibacterial activity, and action mode of the active species. Biomacromolecules 7: 2291-2296.

29. Buranasompob A (2005) Kinetics of the inactivation of microorganisms by water insoluble polymers with antimicrobial activity. Dissertation, Technische Universität Berlin.

30. Brodkorb F, Fischer B, Kalbfleisch K, Robers O, Braun C, et al. (2015) Development of a new monomer for the synthesis of intrinsic antimicrobial polymers with enhanced material properties. Int J Mol Sci 16: 20050-20066.

31. Kreyenschmidt M, Lorenz R, Fischer B (2014) Anti-microbial polymer(WO2014118339 A1).

32. Hechelmann H (1981) Occurrence and Significance of Brochothrix thermosphacta in refrigerated storage of meat and meat products. Bulletin of the Federal Institute for Meat Research, Kulmbach: 4435-4437.

33. Suppakul P, Miltz J, Sonneveld K, Bigger S (2003) Active packaging technologies with an emphasis on antimicrobial packaging and its applications. J Food Sci 68: 408-420. 
Citation: Braun C, Dohlen S, Ilg Y, Brodkorb F, Fischer B, et al. (2017) Antimicrobial Activity of Intrinsic Antimicrobial Polymers Based on Poly((tert-butyl-amino)-methyl-styrene) Against Selected Pathogenic and Spoilage Microorganisms Relevant in Meat Processing Facilities. J Antimicrob Agents 3: 136. doi:10.4172/2472-1212.1000136

Page 9 of 9

34. Seyfriedsberger G, Rametsteiner K, Kern W (2006) Polyethylene compounds with antimicrobial surface properties. Eur Polym J 42: 3383-3389.

35. Potter R, Truelstruphansen L, Gill T (2005) Inhibition of foodborne bacteria by native and modified protamine: Importance of electrostatic interactions. Int J Food Microbiol 103: 23-34.

36. Marra J, Paleari AG, Rodriguez LS, Leite ARP, Pero AC, et al. (2012) Effect of an acrylic resin combined with an antimicrobial polymer on biofilm formation. J Appl Oral Sci 20: 643-648.

37. Zuo H, Wu D, Fu R (2012) Preparation of antibacterial poly(methyl methacrylate) by solution blending with water-insoluble antibacterial agent poly[(tert-butylamino) ethyl methacrylate]. J Appl Polym Sci 125: 3537-3544.

38. Thomassin JM, Lenoir S, Riga J, Jérôme R, Detrembleur C (2007) Grafting of Poly[2-(tert-butylamino)ethyl methacrylate] onto polypropylene by reactive blending and antibacterial activity of the copolymer. Biomacromolecules 8: 1171-1177.

39. Dohlen S, Braun C, Brodkorb F, Fischer B, Ilg Y, et al. (2016) Potential of the polymer poly-[2-(tert-butylamino) methylstyrene] as antimicrobial packaging material for meat products. J Appl Microbiol 121: 1059-1070.
40. Jucker BA, Harms H, Zehnder AJ (1996) Adhesion of the positively charged bacterium Stenotrophomonas (Xanthomonas) maltophilia 70401 to glass and Teflon. J Bacteriol 178: 5472-5479.

41. Kurincic M, Jersek B, Klancnik A, Mozina SS, Fink R, et al. (2016) Effects of natural antimicrobials on bacterial cell hydrophobicity, adhesion, and zeta potential. Arh Hig Rada Toksikol 67: 39-45.

42. Simões M, Simões LC, Vieira MJ (2010) A review of current and emergent biofilm control strategies. LWT-Food Sci Technol 43: 573-583.

43. Sasahara KC, Zottola EA (1993) Biofilm formation by listeria monocytogenes utilizes a primary colonizing microorganism in flowing systems. J Food Prot 56: 1022-1028.

44. Hassan AN, Frank JF (2004) Attachment of Escherichia coli O157: H7 grown in tryptic soy broth and nutrient broth to apple and lettuce surfaces as related to cell hydrophobicity, surface charge, and capsule production. Int J Food Microbiol 96: 103-109.

45. Russo F, Ercolini D, Mauriello G, Villani F (2006) Behaviour of Brochothrix thermosphacta in presence of other meat spoilage microbial groups. Food Microbiol 23: 797-802. 